
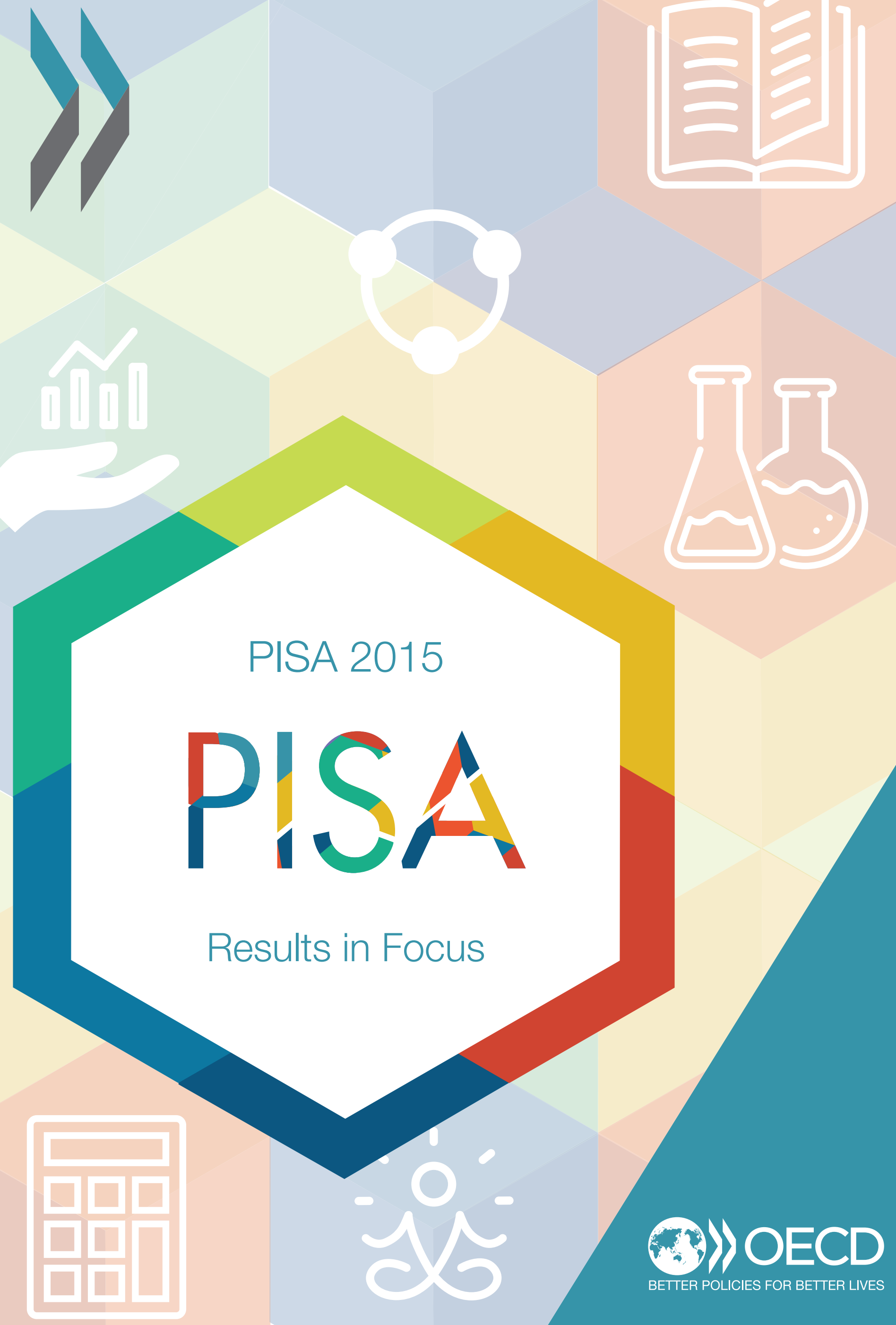


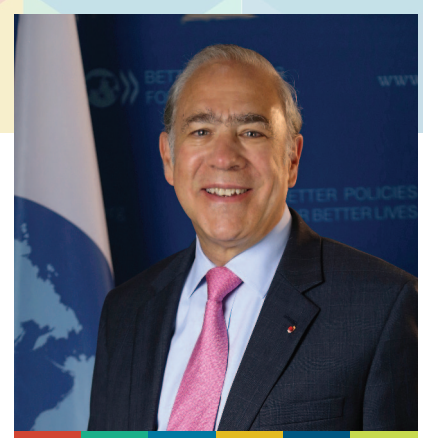

Over the past decade, the OECD Programme for International Student Assessment, PISA, has become the world's premier yardstick for evaluating the quality, equity and efficiency of school systems. By identifying the characteristics of high-performing education systems, PISA allows governments and educators to identify effective policies that they can then adapt to their local contexts.

The latest PISA assessment in 2015 focused on science. From taking a painkiller to determining what is a "balanced" meal, from drinking pasteurised milk to deciding whether or not to buy a hybrid car, science is ubiquitous in our lives. And science is not just test tubes and the periodic table; it is the basis of nearly every tool we use - from a simple can opener to the most advanced space explorer. More important, science is not only the domain of scientists. In the context of massive information flows and rapid change, everyone now needs to be able to "think like a scientist": to be able to weigh evidence and come to a conclusion; to understand that scientific "truth" may change over time, as new discoveries are made, and as humans develop a greater understanding of natural forces and of technology's capacities and limitations.

This brochure highlights some of the results from PISA 2015. PISA shows that every country has room for improvement, even the top performers. With high levels of youth unemployment, rising inequality, a significant gender gap, and an urgent need to boost inclusive growth in many countries, we have no time to lose in providing the best education possible for all students.

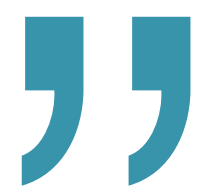




\section{What is PISA?}

"What is important for citizens to know and be able to do?" In response to that question and to the need for internationally comparable evidence on student performance, the Organisation for Economic Co-operation and Development (OECD) launched the triennial survey of 15-year-old students around the world known as the Programme for International Students Assessment, or PISA. PISA assesses the extent to which 15-year-old students, near the end of their compulsory education, have acquired key knowledge and skills that are essential for full participation in modern societies. The assessment focuses on the core school subjects of science, reading and mathematics. Students' proficiency in an innovative domain is also assessed (in 2015, this domain is collaborative problem solving). The assessment does not just ascertain whether students can reproduce knowledge; it also examines how well students can extrapolate from what they have learned and can apply that knowledge in unfamiliar settings, both in and outside of school. This approach reflects the fact that modern economies reward individuals not for what they know, but for what they can do with what they know.

PISA is an ongoing programme that offers insights for education policy and practice, and that helps monitor trends in students' acquisition of knowledge and skills across countries and in different demographic subgroups within each country. PISA results reveal what is possible in education by showing what students in the highest-performing and most rapidly improving education systems can do. The findings allow policy makers around the world to gauge the knowledge and skills of students in their own countries in comparison with those in other countries, set policy targets against measurable goals achieved by other education systems, and learn from policies and practices applied elsewhere. While PISA cannot identify cause-and-effect relationships between policies/practices and student outcomes, it can show educators, policy makers and the interested public how education systems are similar and different - and what that means for students.

\section{Key features of PISA 2015}

Content

- The PISA 2015 survey focused on science, with reading, mathematics and collaborative problem solving as minor areas of assessment. PISA 2015 also included an assessment of young people's financial literacy, which was optional for countries and economies.

\section{Participating students}

- Approximately 540000 students completed the assessment in 2015, representing about 29 million 15-year-olds in the schools of the 72 participating countries and economies.

\section{The assessment}

- Computer-based tests were used, with assessments lasting a total of two hours for each student.

- Test items were a mixture of multiple-choice questions and questions requiring students to construct their own responses. The items were organised in groups based on a passage setting out a real-life situation. About 810 minutes of test items for science, reading, mathematics and collaborative problem solving were covered, with different students taking different combinations of test items.

- Students also answered a background questionnaire, which took 35 minutes to complete. The questionnaire sought information about the students themselves, their homes, and their school and learning experiences. School principals completed a questionnaire that covered the school system and the learning environment. For additional information, some countries/economies decided to distribute a questionnaire to teachers. It was the first time that this optional teacher questionnaire was offered to PISA-participating countries/ economies. In some countries/economies, optional questionnaires were distributed to parents, who were asked to provide information on their perceptions of and involvement in their child's school, their support for learning in the home, and their child's career expectations, particularly in science. Countries could choose two other optional questionnaires for students: one asked students about their familiarity with and use of information and communication technologies; and the second sought information about students' education to date, including any interruptions in their schooling, and whether and how they are preparing for a future career. 


\section{Excellence and equity in education}

\section{What the data tell us}

\section{Students' performance in science and attitudes towards science}

- Singapore outperforms all other participating countries/economies in science. Japan, Estonia, Finland and Canada, in descending order of mean science performance, are the four highestperforming OECD countries.

- Some $8 \%$ of students across OECD countries (and 24\% of students in Singapore) are top performers in science, meaning that they are proficient at Level 5 or 6 . Students at these levels are sufficiently skilled in and knowledgeable about science to creatively and autonomously apply their knowledge and skills to a wide variety of situations, including unfamiliar ones.

- About $20 \%$ of students across OECD countries perform below Level 2, considered the baseline level of proficiency in science. At Level 2, students can draw on their knowledge of basic science content and procedures to identify an appropriate explanation, interpret data, and identify the question being addressed in a simple experiment. All students should be expected to attain Level 2 by the time they leave compulsory education.

- In the majority of countries with comparable data, students' performance in science remained essentially unchanged since 2006. However, mean performance in science improved between 2006 and 2015 in Colombia, Israel, Macao (China), Portugal, Qatar and Romania. Over this period, Macao (China), Portugal and Qatar increased the share of students performing at or above Level 5 and simultaneously reduced the share of students performing below the baseline level of proficiency (Level 2).

- Even though gender differences in science performance tend to be small, on average, in 33 countries and economies, the share of top performers in science is larger among boys than among girls. Finland is the only country in which girls are more likely to be top performers than boys.

- On average across OECD countries, 25\% of boys and 24\% of girls reported that they expect to work in a science-related occupation. But boys and girls tend to think of working in different fields of science: girls envisage themselves as health professionals more than boys do; and in almost all countries, boys see themselves as becoming information and communications technologies (ICT) professionals, scientists or engineers more than girls do.

\section{Students' performance in reading and mathematics}

- About $20 \%$ of students in OECD countries, on average, do not attain the baseline level of proficiency in reading. This proportion has remained stable since 2009 .

- On average across OECD countries, the gender gap in reading in favour of girls narrowed by 12 points between 2009 and 2015: boys' performance improved, particularly among the highest-achieving boys, while girls' performance deteriorated, particularly among the lowest-achieving girls.

- More than one in four students in Beijing-Shanghai-JiangsuGuangdong (China), Hong Kong (China), Singapore and Chinese Taipei are top-performing students in mathematics, meaning that they can handle tasks that require the ability to formulate complex situations mathematically, using symbolic representations.

\section{Equity in education}

- Canada, Denmark, Estonia, Hong Kong (China) and Macao (China) achieve high levels of performance and equity in education outcomes.

- Socio-economically disadvantaged students across OECD countries are almost three times more likely than advantaged students not to attain the baseline level of proficiency in science. But about 29\% of disadvantaged students are considered resilient - meaning that they beat the odds and perform at high levels. And in Macao (China) and Viet Nam, students facing the greatest disadvantage on an international scale outperform the most advantaged students in about 20 other PISA-participating countries and economies.

- While between 2006 and 2015 no country or economy improved its performance in science and equity in education simultaneously, the relationship between socio-economic status and student performance weakened in nine countries where mean science scores remained stable. The United States shows the largest improvements in equity during this period.

- On average across OECD countries, and after taking their socioeconomic status into account, immigrant students are more than twice as likely as their non-immigrant peers to perform below the baseline level of proficiency in science. Yet 24\% of disadvantaged immigrant students are considered resilient.

- On average across countries with relatively large immigrant student populations, attending a school with a high concentration of immigrant students is not associated with poorer student performance, after accounting for the school's socio-economic intake. 


\begin{tabular}{|c|}
\hline $\begin{array}{c}\text { Countries/economies with a mean performance/share of top performers above the OECD average } \\
\text { Countries/economies with a share of low achievers below the OECD average }\end{array}$ \\
\hline Countries/economies with a mean performance/share of top performers/share of low achievers not significantly different from the OECD average \\
\hline Countries/economies with a mean performance/share of top performers below the OECD average \\
Countries/economies with a share of low achievers above the OECD average
\end{tabular}

\begin{tabular}{|c|c|c|c|c|c|c|c|c|}
\hline & \multicolumn{2}{|c|}{ Science } & \multicolumn{2}{|c|}{ Reading } & \multicolumn{2}{|c|}{ Mathematics } & \multicolumn{2}{|c|}{ Science, reading and mathematics } \\
\hline & $\begin{array}{l}\text { Mean score } \\
\text { in PISA 2015 }\end{array}$ & $\begin{array}{c}\text { Average } \\
\text { three-year trend }\end{array}$ & $\begin{array}{l}\text { Mean score } \\
\text { in PISA } 2015\end{array}$ & $\begin{array}{l}\text { Average three- } \\
\text { year trend }\end{array}$ & $\begin{array}{l}\text { Mean score } \\
\text { in PISA } 2015\end{array}$ & $\begin{array}{c}\text { Average } \\
\text { three-year trend }\end{array}$ & $\begin{array}{l}\text { Share of top performers in at } \\
\text { least one subject (Level } 5 \text { or } 6 \text { ) }\end{array}$ & $\begin{array}{l}\text { Share of low achievers in all } \\
\text { three subjects (below Level 2) }\end{array}$ \\
\hline & Mean & Score dif. & Mean & Score dif. & Mean & Score dif. & $\%$ & $\%$ \\
\hline $\mathrm{OECD}$ average & 493 & -1 & 493 & -1 & 490 & -1 & 15.3 & 13.0 \\
\hline Singapore & 556 & 7 & 535 & 5 & 564 & 1 & 39.1 & 4.8 \\
\hline Japan & 538 & 3 & 516 & -2 & 532 & 1 & 25.8 & 5.6 \\
\hline Estonia & 534 & 2 & 519 & 9 & 520 & 2 & 20.4 & 4.7 \\
\hline Chinese Taipei & 532 & 0 & 497 & 1 & 542 & 0 & 29.9 & 8.3 \\
\hline Finland & 531 & -11 & 526 & -5 & 511 & -10 & 21.4 & 6.3 \\
\hline Macao (China) & 529 & 6 & 509 & 11 & 544 & 5 & 23.9 & 3.5 \\
\hline Canada & 528 & -2 & 527 & 1 & 516 & -4 & 22.7 & 5.9 \\
\hline Viet Nam & 525 & -4 & 487 & -21 & 495 & -17 & 12.0 & 4.5 \\
\hline Hong Kong (China) & 523 & -5 & 527 & -3 & 548 & 1 & 29.3 & 4.5 \\
\hline B-S-J-G (China) & 518 & $\mathrm{~m}$ & 494 & $\mathrm{~m}$ & 531 & $\mathrm{~m}$ & 27.7 & 10.9 \\
\hline Korea & 516 & -2 & 517 & -11 & 524 & -3 & 25.6 & 7.7 \\
\hline New Zealand & 513 & -7 & 509 & -6 & 495 & -8 & 20.5 & 10.6 \\
\hline Slovenia & 513 & -2 & 505 & 11 & 510 & 2 & 18.1 & 8.2 \\
\hline Australia & 510 & -6 & 503 & -6 & 494 & -8 & 18.4 & 11.1 \\
\hline United Kingdom & 509 & -1 & 498 & 2 & 492 & -1 & 16.9 & 10.1 \\
\hline Germany & 509 & -2 & 509 & 6 & 506 & 2 & 19.2 & 9.8 \\
\hline Netherlands & 509 & -5 & 503 & -3 & 512 & -6 & 20.0 & 10.9 \\
\hline Switzerland & 506 & -2 & 492 & -4 & 521 & -1 & 22.2 & 10.1 \\
\hline Ireland & 503 & 0 & 521 & 13 & 504 & 0 & 15.5 & 6.8 \\
\hline Belgium & 502 & -3 & 499 & -4 & 507 & -5 & 19.7 & 12.7 \\
\hline Denmark & 502 & 2 & 500 & 3 & 511 & -2 & 14.9 & 7.5 \\
\hline Poland & 501 & 3 & 506 & 3 & 504 & 5 & 15.8 & 8.3 \\
\hline Portugal & 501 & 8 & 498 & 4 & 492 & 7 & 15.6 & 10.7 \\
\hline Norway & 498 & 3 & 513 & 5 & 502 & 1 & 17.6 & 8.9 \\
\hline United States & 496 & 2 & 497 & -1 & 470 & -2 & 13.3 & 13.6 \\
\hline Austria & 495 & -5 & 485 & -5 & 497 & -2 & 16.2 & 13.5 \\
\hline France & 495 & 0 & 499 & 2 & 493 & -4 & 18.4 & 14.8 \\
\hline Sweden & 493 & -4 & 500 & 1 & 494 & -5 & 16.7 & 11.4 \\
\hline Czech Republic & 493 & -5 & 487 & 5 & 492 & -6 & 14.0 & 13.7 \\
\hline Spain & 493 & 2 & 496 & 7 & 486 & 1 & 10.9 & 10.3 \\
\hline Latvia & 490 & 1 & 488 & 2 & 482 & 0 & 8.3 & 10.5 \\
\hline Russia & 487 & 3 & 495 & 17 & 494 & 6 & 13.0 & 7.7 \\
\hline Luxembourg & 483 & 0 & 481 & 5 & 486 & -2 & 14.1 & 17.0 \\
\hline Italy & 481 & 2 & 485 & 0 & 490 & 7 & 13.5 & 12.2 \\
\hline Hungary & 477 & -9 & 470 & -12 & 477 & -4 & 10.3 & 18.5 \\
\hline Lithuania & 475 & -3 & 472 & 2 & 478 & -2 & 9.5 & 15.3 \\
\hline Croatia & 475 & -5 & 487 & 5 & 464 & 0 & 9.3 & 14.5 \\
\hline CABA (Argentina) & 475 & 51 & 475 & 46 & 456 & 38 & 7.5 & 14.5 \\
\hline Iceland & 473 & -7 & 482 & -9 & 488 & -7 & 13.2 & 13.2 \\
\hline Israel & 467 & 5 & 479 & 2 & 470 & 10 & 13.9 & 20.2 \\
\hline Malta & 465 & 2 & 447 & 3 & 479 & 9 & 15.3 & 21.9 \\
\hline Slovak Republic & 461 & -10 & 453 & -12 & 475 & -6 & 9.7 & 20.1 \\
\hline Greece & 455 & -6 & 467 & -8 & 454 & 1 & 6.8 & 20.7 \\
\hline Chile & 447 & 2 & 459 & 5 & 423 & 4 & 3.3 & 23.3 \\
\hline Bulgaria & 446 & 4 & 432 & 1 & 441 & 9 & 6.9 & 29.6 \\
\hline United Arab Emirates & 437 & -12 & 434 & -8 & 427 & -7 & 5.8 & 31.3 \\
\hline Uruguay & 435 & 1 & 437 & 5 & 418 & -3 & 3.6 & 30.8 \\
\hline Romania & 435 & 6 & 434 & 4 & 444 & 10 & 4.3 & 24.3 \\
\hline Cyprus $^{1}$ & 433 & -5 & 443 & -6 & 437 & -3 & 5.6 & 26.1 \\
\hline Moldova & 428 & 9 & 416 & 17 & 420 & 13 & 2.8 & 30.1 \\
\hline Albania & 427 & 18 & 405 & 10 & 413 & 18 & 2.0 & 31.1 \\
\hline Turkey & 425 & 2 & 428 & -18 & 420 & 2 & 1.6 & 31.2 \\
\hline Trinidad and Tobago & 425 & 7 & 427 & 5 & 417 & 2 & 4.2 & 32.9 \\
\hline Thailand & 421 & 2 & 409 & -6 & 415 & 1 & 1.7 & 35.8 \\
\hline Costa Rica & 420 & -7 & 427 & -9 & 400 & -6 & 0.9 & 33.0 \\
\hline Qatar & 418 & 21 & 402 & 15 & 402 & 26 & 3.4 & 42.0 \\
\hline Colombia & 416 & 8 & 425 & 6 & 390 & 5 & 1.2 & 38.2 \\
\hline Mexico & 416 & 2 & 423 & -1 & 408 & 5 & 0.6 & 33.8 \\
\hline Montenegro & 411 & 1 & 427 & 10 & 418 & 6 & 2.5 & 33.0 \\
\hline Georgia & 411 & 23 & 401 & 16 & 404 & 15 & 2.6 & 36.3 \\
\hline Jordan & 409 & -5 & 408 & 2 & 380 & -1 & 0.6 & 35.7 \\
\hline Indonesia & 403 & 3 & 397 & -2 & 386 & 4 & 0.8 & 42.3 \\
\hline Brazil & 401 & 3 & 407 & -2 & 377 & 6 & 2.2 & 44.1 \\
\hline Peru & 397 & 14 & 398 & 14 & 387 & 10 & 0.6 & 46.7 \\
\hline Lebanon & 386 & $\mathrm{~m}$ & 347 & $\mathrm{~m}$ & 396 & $\mathrm{~m}$ & 2.5 & 50.7 \\
\hline Tunisia & 386 & 0 & 361 & -21 & 367 & 4 & 0.6 & 57.3 \\
\hline FYROM & 384 & $\mathrm{~m}$ & 352 & $\mathrm{~m}$ & 371 & $\mathrm{~m}$ & 1.0 & 52.2 \\
\hline Kosovo & 378 & $\mathrm{~m}$ & 347 & $\mathrm{~m}$ & 362 & $\mathrm{~m}$ & 0.0 & 60.4 \\
\hline Algeria & 376 & $\mathrm{~m}$ & 350 & $\mathrm{~m}$ & 360 & $\mathrm{~m}$ & 0.1 & 61.1 \\
\hline Dominican Republic & 332 & $\mathrm{~m}$ & 358 & $\mathrm{~m}$ & 328 & $\mathrm{~m}$ & 0.1 & 70.7 \\
\hline
\end{tabular}

1. Note by Turkey: The information in this document with reference to "Cyprus" relates to the southern part of the Island. There is no single authority representing both Turkish and Greek Cypriot people on the Island. Turkey recognises the Turkish Republic of Northern Cyprus (TRNC). Until a lasting and equitable solution is found within the context of the United Nations, Turkey shall preserve its position concerning the "Cyprus issue".

Note by all the European Union Member States of the OECD and the European Union: The Republic of Cyprus is recognised by all members of the United Nations with the exception of Turkey. The information in this document relates to the area under the effective control of the Government of the Republic of Cyprus.

Notes: Values that are statistically significant are marked in bold.

The average trend is reported for the longest available period since PISA 2006 for science, PISA 2009 for reading, and PISA 2003 for mathematics.

Countries and economies are ranked in descending order of the mean science score in PISA 2015.

Source: OECD, PISA 2015 Database, Tables I.2.4a, I.2.6, I.2.7, I.4.4a and I.5.4a. 
At a time when science literacy is increasingly linked to economic growth and is necessary for finding solutions to complex social and environmental problems, all citizens, not just future scientists and engineers, need to be willing and able to confront science-related dilemmas.

For most of the 20th century, school science curricula, especially in upper secondary education, tended to focus on providing the foundations for the training of a small number of scientists and engineers. These curricula mostly presented science in a form that focused on providing students with the basic facts, laws or theories related to the various disciplines of science rather than on the broader concepts of scientific enquiry and the evolving nature of scientific "truth". Based on students' ability to master those facts and theories, educators tended to identify students who could continue to study science beyond compulsory education, rather than encouraging every student to be engaged with science.

Promoting a positive and inclusive image of science is important. Too often, school science is seen as the first segment of a (leaky) pipeline that will ultimately select those who will work as scientists and engineers. Not only does the "pipeline" metaphor discount the many pathways successful scientists have travelled to reach their career goals, it also conveys a negative image of those who do not end up as scientists and engineers. Because knowledge and understanding of science is useful well beyond the work of scientists and is, as PISA argues, necessary for full participation in a world shaped by science-based technology, school science should be promoted more positively - perhaps as a "springboard" to new sources of interest and enjoyment.

\section{Parents and teachers can challenge gender stereotypes about science-related activities and occupations to allow girls and boys to achieve their potential.}

Among the subjects of science, mathematics and reading, science is the one where mean gender differences in performance in PISA are smallest; and these differences vary significantly across countries. This indicates that gender disparities in performance do not stem from innate differences in aptitude, but rather from factors that parents, teachers, policy makers and opinion leaders can influence.
Most students who sat the PISA 2015 test expressed a broad interest in science topics and recognised the important role that science plays in their world; but only a minority of students reported that they participate in science activities. Boys and girls, and students from advantaged and disadvantaged backgrounds, often differ in the ways they engage with science and envisage themselves working in science-related occupations later on. Gender-related differences in science engagement and career expectations appear more related to disparities in what boys and girls think they are good at and is good for them, than to differences in what they actually can do.

Stereotypes about scientists and about work in science-related occupations (computer science is a "masculine" field and biology a "feminine" field; scientists achieve success due to brilliance rather than hard work; scientists are "mad") can discourage some students from engaging further with science. In addition to challenging gender stereotypes, parents and teachers can help support students' engagement with science by helping students become more aware of the range of career opportunities that are made available with training in science and technology.

The most immediate way to nurture interest in science among students with less supportive home environments may be to increase early exposure to high-quality science instruction in schools.

PISA 2015 shows that, in most participating countries and economies, socio-economic status and an immigrant background are associated with significant differences in student performance. For example, disadvantaged students score 88 points lower in science than advantaged students, on average across OECD countries. And in more than 40 countries and economies, and after accounting for students' performance in the science assessment, disadvantaged students remain significantly less likely than their advantaged peers to see themselves pursuing a career in science.

Yet PISA also shows that the relationship between students' background and their outcomes in education varies widely across countries. In some high-performing countries, this relationship is weaker than average - implying that high achievement and equity in education outcomes are not mutually exclusive. This underlines PISA's definition of equity as high performance among students from all backgrounds, rather than as small variations in student performance only. In PISA 2015, Canada, Denmark, Estonia, Hong Kong (China) and Macao (China) achieved both high levels of performance and greater equity in education. 
Snapshot of students' science beliefs, engagement and motivation

\begin{tabular}{|c|c|c|c|c|c|c|c|c|c|c|}
\hline & \multicolumn{10}{|c|}{ Countries/economies with values above the OECD average } \\
\hline & \multicolumn{10}{|c|}{ Countries/economies with values not significantly different from the OECD average } \\
\hline & \multicolumn{10}{|c|}{ Countries/economies with values below the OECD average } \\
\hline & \multirow[b]{2}{*}{$\begin{array}{l}\text { Mean } \\
\text { science } \\
\text { score }\end{array}$} & \multicolumn{2}{|c|}{$\begin{array}{l}\text { Beliefs about the nature and origin } \\
\text { of scientific knowledge }\end{array}$} & Share o & lents wit & ce-relat & reer expectations & & tivation for learning scier & \\
\hline & & $\begin{array}{c}\text { Index of epistemic } \\
\text { beliefs (support for } \\
\text { scientific methods } \\
\text { of enquiry) }\end{array}$ & $\begin{array}{l}\text { Score-point } \\
\text { difference per unit } \\
\text { on the index of } \\
\text { epistemic beliefs }\end{array}$ & $\begin{array}{c}\text { All } \\
\text { students }\end{array}$ & Boys & Girls & $\begin{array}{c}\text { Increased } \\
\text { likelihood of boys } \\
\text { expecting a career } \\
\text { in science }\end{array}$ & $\begin{array}{c}\text { Index of } \\
\text { enjoyment of } \\
\text { learning science }\end{array}$ & $\begin{array}{l}\text { Score-point difference } \\
\text { per unit on the index of } \\
\text { enjoyment of learning } \\
\text { science }\end{array}$ & $\begin{array}{l}\text { Gender gap in } \\
\text { enjoyment of } \\
\text { learning science } \\
\text { (Boys - Girls) }\end{array}$ \\
\hline & Mean & Mean index & Score dif. & $\%$ & $\%$ & $\%$ & Relative risk & Mean index & Score dif. & Dif. \\
\hline OECD average & 493 & 0.00 & 33 & 24.5 & 25.0 & 23.9 & 1.1 & 0.02 & 25 & 0.13 \\
\hline Singapore & 556 & 0.22 & 34 & 28.0 & 31.8 & 23.9 & 1.3 & 0.59 & 35 & 0.17 \\
\hline Japan & 538 & -0.06 & 34 & 18.0 & 18.5 & 17.5 & 1.1 & -0.33 & 27 & 0.52 \\
\hline Estonia & 534 & 0.01 & 36 & 24.7 & 28.9 & 20.3 & 1.4 & 0.16 & 24 & 0.05 \\
\hline Chinese Taipei & 532 & 0.31 & 38 & 20.9 & 25.6 & 16.0 & 1.6 & -0.06 & 28 & 0.39 \\
\hline Finland & 531 & -0.07 & 38 & 17.0 & 15.4 & 18.7 & 0.8 & -0.07 & 30 & 0.04 \\
\hline Macao (China) & 529 & -0.06 & 26 & 20.8 & 22.0 & 19.6 & 1.1 & 0.20 & 21 & 0.16 \\
\hline Canada & 528 & 0.30 & 29 & 33.9 & 31.2 & 36.5 & 0.9 & 0.40 & 26 & 0.15 \\
\hline Viet Nam & 525 & -0.15 & 31 & 19.6 & 21.2 & 18.1 & 1.2 & 0.65 & 14 & 0.06 \\
\hline Hong Kong (China) & 523 & 0.04 & 23 & 23.6 & 22.9 & 24.2 & 0.9 & 0.28 & 20 & 0.26 \\
\hline B-S-J-G (China) & 518 & -0.08 & 37 & 16.8 & 17.1 & 16.5 & 1.0 & 0.37 & 28 & 0.14 \\
\hline Korea & 516 & 0.02 & 38 & 19.3 & 21.7 & 16.7 & 1.3 & -0.14 & 31 & 0.32 \\
\hline New Zealand & 513 & 0.22 & 40 & 24.8 & 21.7 & 27.9 & 0.8 & 0.20 & 32 & 0.03 \\
\hline Slovenia & 513 & 0.07 & 33 & 30.8 & 34.6 & 26.8 & 1.3 & -0.36 & 22 & -0.03 \\
\hline Australia & 510 & 0.26 & 39 & 29.2 & 30.3 & 28.2 & 1.1 & 0.12 & 33 & 0.16 \\
\hline United Kingdom & 509 & 0.22 & 37 & 29.1 & 28.7 & 29.6 & 1.0 & 0.15 & 30 & 0.18 \\
\hline Germany & 509 & -0.16 & 34 & 15.3 & 17.4 & 13.2 & 1.3 & -0.18 & 29 & 0.43 \\
\hline Netherlands & 509 & -0.19 & 46 & 16.3 & 16.9 & 15.7 & 1.1 & -0.52 & 30 & 0.25 \\
\hline Switzerland & 506 & -0.07 & 34 & 19.5 & 19.8 & 19.1 & 1.0 & -0.02 & 30 & 0.17 \\
\hline Ireland & 503 & 0.21 & 36 & 27.3 & 28.0 & 26.6 & 1.1 & 0.20 & 32 & 0.09 \\
\hline Belgium & 502 & 0.00 & 34 & 24.5 & 25.3 & 23.6 & 1.1 & -0.03 & 28 & 0.20 \\
\hline Denmark & 502 & 0.17 & 32 & 14.8 & 11.8 & 17.7 & 0.7 & 0.12 & 26 & 0.09 \\
\hline Poland & 501 & -0.08 & 27 & 21.0 & 15.4 & 26.8 & 0.6 & 0.02 & 18 & -0.10 \\
\hline Portugal & 501 & 0.28 & 33 & 27.5 & 26.7 & 28.3 & 0.9 & 0.32 & 23 & 0.08 \\
\hline Norway & 498 & -0.01 & 35 & 28.6 & 28.9 & 28.4 & 1.0 & 0.12 & 29 & 0.27 \\
\hline United States & 496 & 0.25 & 32 & 38.0 & 33.0 & 43.0 & 0.8 & 0.23 & 26 & 0.21 \\
\hline Austria & 495 & -0.14 & 36 & 22.3 & 26.6 & 18.0 & 1.5 & -0.32 & 25 & 0.23 \\
\hline France & 495 & 0.01 & 30 & 21.2 & 23.6 & 18.7 & 1.3 & -0.03 & 30 & 0.31 \\
\hline Sweden & 493 & 0.14 & 38 & 20.2 & 21.8 & 18.5 & 1.2 & 0.08 & 27 & 0.22 \\
\hline Czech Republic & 493 & -0.23 & 41 & 16.9 & 18.6 & 15.0 & 1.2 & -0.34 & 27 & -0.06 \\
\hline Spain & 493 & 0.11 & 30 & 28.6 & 29.5 & 27.8 & 1.1 & 0.03 & 28 & 0.11 \\
\hline Latvia & 490 & -0.26 & 27 & 21.3 & 21.1 & 21.5 & 1.0 & 0.09 & 18 & 0.03 \\
\hline Russia & 487 & -0.26 & 27 & 23.5 & 23.2 & 23.8 & 1.0 & 0.00 & 16 & 0.07 \\
\hline Luxembourg & 483 & -0.15 & 35 & 21.1 & 24.3 & 18.0 & 1.4 & 0.10 & 26 & 0.14 \\
\hline Italy & 481 & -0.10 & 34 & 22.6 & 24.7 & 20.6 & 1.2 & 0.00 & 22 & 0.24 \\
\hline Hungary & 477 & -0.36 & 35 & 18.3 & 23.9 & 12.8 & 1.9 & -0.23 & 20 & -0.02 \\
\hline Lithuania & 475 & 0.11 & 22 & 23.9 & 22.5 & 25.4 & 0.9 & 0.36 & 20 & -0.14 \\
\hline Croatia & 475 & 0.03 & 32 & 24.2 & 26.8 & 21.8 & 1.2 & -0.11 & 22 & 0.05 \\
\hline CABA (Argentina) & 475 & 0.09 & 28 & 27.8 & 26.2 & 29.3 & 0.9 & -0.20 & 15 & -0.14 \\
\hline Iceland & 473 & 0.29 & 28 & 23.8 & 20.1 & 27.3 & 0.7 & 0.15 & 24 & 0.26 \\
\hline Israel & 467 & 0.18 & 38 & 27.8 & 26.1 & 29.5 & 0.9 & 0.09 & 20 & 0.06 \\
\hline Malta & 465 & 0.09 & 54 & 25.4 & 30.2 & 20.4 & 1.5 & 0.18 & 48 & 0.11 \\
\hline Slovak Republic & 461 & -0.35 & 36 & 18.8 & 18.5 & 19.0 & 1.0 & -0.24 & 25 & -0.02 \\
\hline Greece & 455 & -0.19 & 36 & 25.3 & 25.7 & 24.9 & 1.0 & 0.13 & 27 & 0.12 \\
\hline Chile & 447 & -0.15 & 23 & 37.9 & 36.9 & 39.0 & 0.9 & 0.08 & 15 & -0.09 \\
\hline Bulgaria & 446 & -0.18 & 34 & 27.5 & 28.8 & 25.9 & 1.1 & 0.28 & 17 & -0.16 \\
\hline United Arab Emirates & 437 & 0.04 & 33 & 41.3 & 39.9 & 42.6 & 0.9 & 0.47 & 22 & -0.02 \\
\hline Uruguay & 435 & -0.13 & 27 & 28.1 & 23.8 & 31.9 & 0.7 & -0.10 & 16 & -0.07 \\
\hline Romania & 435 & -0.38 & 27 & 23.1 & 23.3 & 23.0 & 1.0 & -0.03 & 17 & -0.05 \\
\hline Cyprus $^{1}$ & 433 & -0.15 & 33 & 29.9 & 29.3 & 30.5 & 1.0 & 0.15 & 29 & 0.06 \\
\hline Moldova & 428 & -0.14 & 37 & 22.0 & 22.5 & 21.3 & 1.1 & 0.33 & 22 & -0.17 \\
\hline Albania & 427 & -0.03 & $\mathrm{~m}$ & 24.8 & $\mathrm{~m}$ & $\mathrm{~m}$ & $\mathrm{~m}$ & 0.72 & $\mathrm{~m}$ & $\mathrm{~m}$ \\
\hline Turkey & 425 & -0.17 & 18 & 29.7 & 34.5 & 24.9 & 1.4 & 0.15 & 12 & 0.01 \\
\hline Trinidad and Tobago & 425 & -0.02 & 28 & 27.8 & 24.6 & 31.0 & 0.8 & 0.19 & 24 & -0.01 \\
\hline Thailand & 421 & -0.07 & 35 & 19.7 & 12.4 & 25.2 & 0.5 & 0.42 & 18 & -0.05 \\
\hline Costa Rica & 420 & -0.15 & 16 & 44.0 & 43.8 & 44.2 & 1.0 & 0.35 & 4 & -0.03 \\
\hline Qatar & 418 & -0.10 & 33 & 38.0 & 36.3 & 39.9 & 0.9 & 0.36 & 25 & 0.00 \\
\hline Colombia & 416 & -0.19 & 21 & 39.7 & 37.1 & 42.0 & 0.9 & 0.32 & 7 & -0.02 \\
\hline Mexico & 416 & -0.17 & 17 & 40.7 & 45.4 & 35.8 & 1.3 & 0.42 & 12 & 0.01 \\
\hline Montenegro & 411 & -0.32 & 23 & 21.2 & 20.1 & 22.4 & 0.9 & 0.09 & 14 & -0.07 \\
\hline Georgia & 411 & 0.05 & 42 & 17.0 & 16.4 & 17.7 & 0.9 & 0.34 & 23 & -0.13 \\
\hline Jordan & 409 & -0.13 & 28 & 43.7 & 44.6 & 42.8 & 1.0 & 0.53 & 23 & -0.25 \\
\hline Indonesia & 403 & -0.30 & 16 & 15.3 & 8.6 & 22.1 & 0.4 & 0.65 & 6 & -0.06 \\
\hline Brazil & 401 & -0.07 & 27 & 38.8 & 34.4 & 42.8 & 0.8 & 0.23 & 19 & -0.04 \\
\hline Peru & 397 & -0.16 & 23 & 38.7 & 42.7 & 34.6 & 1.2 & 0.40 & 9 & 0.01 \\
\hline Lebanon & 386 & -0.24 & 35 & 39.7 & 41.0 & 38.5 & 1.1 & 0.38 & 32 & -0.04 \\
\hline Tunisia & 386 & -0.31 & 18 & 34.4 & 28.5 & 39.5 & 0.7 & 0.52 & 15 & -0.12 \\
\hline FYROM & 384 & -0.18 & 30 & 24.2 & 20.0 & 28.8 & 0.7 & 0.48 & 17 & -0.29 \\
\hline Kosovo & 378 & 0.03 & 22 & 26.4 & 24.7 & 28.1 & 0.9 & 0.92 & 14 & -0.16 \\
\hline Algeria & 376 & -0.31 & 16 & 26.0 & 23.1 & 29.2 & 0.8 & 0.46 & 14 & -0.12 \\
\hline Dominican Republic & 332 & -0.10 & 13 & 45.7 & 44.7 & 46.8 & 1.0 & 0.54 & 6 & -0.05 \\
\hline
\end{tabular}

1. Note by Turkey: The information in this document with reference to "Cyprus" relates to the southern part of the Island. There is no single authority representing both Turkish and Greek Cypriot people on the Island. Turkey recognises the Turkish Republic of Northern Cyprus (TRNC). Until a lasting and equitable solution is found within the context of the United Nations, Turkey shall preserve its position concerning the "Cyprus issue".

Note by all the European Union Member States of the OECD and the European Union: The Republic of Cyprus is recognised by all members of the United Nations with the exception of Turkey. The information in this document relates to the area under the effective control of the Government of the Republic of Cyprus.

Notes: Values that are statistically significant are marked in bold.

Countries and economies are ranked in descending order of the mean science score in PISA 2015.

Source: OECD, PISA 2015 Database, Tables I.2.12a-b, I.3.1a-c and I.3.10a-b. 
For disadvantaged students and those who struggle with science, additional resources, targeted either to individual students or to disadvantaged schools, can make a difference in helping students acquire a baseline level of science literacy and develop a lifelong interest in the subject. All students, whether immigrant or nonimmigrant, advantaged or disadvantaged, would also benefit from a more limited application of policies that sort students into different programme tracks or schools, particularly if these policies are applied in the earliest years of secondary school. These policies often contribute to disparities in the amount and depth of science instruction received by students from different backgrounds. Specific programmes might be needed to spark interest in science among students who may not receive such stimulation outside of school, and to support students' decision to pursue further studies in science. Giving students more opportunities to learn science will help them to learn to "think like a scientist" - a skill that has become all but essential in the 21 s century, even if students choose not to work in a sciencerelated career later on.
1. ESCS refers to the PISA index of economic, social and cultural status.

2. All score-point differences in science performance associated with a one-unit increase on the PISA index of economic, social and cultural status are statistically significant.

3. A student is classified as resilient if he or she is in the bottom quarter of the PISA index of economic social and cultural status in the country/economy of assessment and performs in the top quarter of students among all countries/economies, after accounting for socio-economic status.

4. A positive score indicates a performance difference in favour of non-immigrant students; a negative score indicates a performance difference in favour of immigrant students.

5. Note by Turkey: The information in this document with reference to "Cyprus" relates to the southern part of the Island. There is no single authority representing both Turkish and Greek Cypriot people on the Island. Turkey recognises the Turkish Republic of Northern Cyprus (TRNC). Until a lasting and equitable solution is found within the context of the United Nations, Turkey shall preserve its position concerning the "Cyprus issue".

Note by all the European Union Member States of the OECD and the European Union: The Republic of Cyprus is recognised by all members of the United Nations with the exception of Turkey. The information in this document relates to the area under the effective control of the Government of the Republic of Cyprus.

Notes: Values that are statistically significant are marked in bold.

Countries and economies are ranked in descending order of the mean science score in PISA 2015. Source: OECD, PISA 2015 Database, Tables I.2.3, I.6.1, I.6.3a, I.6.7, I.6.17, I.7.1 and I.7.15a.

\begin{tabular}{|c|c|c|c|}
\hline & $\begin{array}{l}\text { Mean science score } \\
\text { in PISA } 2015\end{array}$ & $\begin{array}{l}\text { Coverage of the national } \\
15 \text {-year-old population } \\
\text { (PISA Coverage index } 3 \text { ) }\end{array}$ & $\begin{array}{l}\text { Percentage of variation } \\
\text { in science performance } \\
\text { explained by students' } \\
\text { socio-economic status }\end{array}$ \\
\hline & Mean & Mean index & $\%$ \\
\hline OECD average & 493 & 0.89 & 12.9 \\
\hline Singapore & 556 & 0.96 & 17 \\
\hline Japan & 538 & 0.95 & 10 \\
\hline Estonia & 534 & 0.93 & 8 \\
\hline Chinese Taipei & 532 & 0.85 & 14 \\
\hline Finland & 531 & 0.97 & 10 \\
\hline Macao (China) & 529 & 0.88 & 2 \\
\hline Canada & 528 & 0.84 & 9 \\
\hline Viet Nam & 525 & 0.49 & 11 \\
\hline Hong Kong (China) & 523 & 0.89 & 5 \\
\hline B-S-J-G (China) & 518 & 0.64 & 18 \\
\hline Korea & 516 & 0.92 & 10 \\
\hline New Zealand & 513 & 0.90 & 14 \\
\hline Slovenia & 513 & 0.93 & 13 \\
\hline Australia & 510 & 0.91 & 12 \\
\hline United Kingdom & 509 & 0.84 & 11 \\
\hline Germany & 509 & 0.96 & 16 \\
\hline Netherlands & 509 & 0.95 & 13 \\
\hline Switzerland & 506 & 0.96 & 16 \\
\hline Ireland & 503 & 0.96 & 13 \\
\hline Belgium & 502 & 0.93 & 19 \\
\hline Denmark & 502 & 0.89 & 10 \\
\hline Poland & 501 & 0.91 & 13 \\
\hline Portugal & 501 & 0.88 & 15 \\
\hline Norway & 498 & 0.91 & 8 \\
\hline United States & 496 & 0.84 & 11 \\
\hline Austria & 495 & 0.83 & 16 \\
\hline France & 495 & 0.91 & 20 \\
\hline Sweden & 493 & 0.94 & 12 \\
\hline Czech Republic & 493 & 0.94 & 19 \\
\hline Spain & 493 & 0.91 & 13 \\
\hline Latvia & 490 & 0.89 & 9 \\
\hline Russia & 487 & 0.95 & 7 \\
\hline Luxembourg & 483 & 0.88 & 21 \\
\hline Italy & 481 & 0.80 & 10 \\
\hline Hungary & 477 & 0.90 & 21 \\
\hline Lithuania & 475 & 0.90 & 12 \\
\hline Croatia & 475 & 0.91 & 12 \\
\hline CABA (Argentina) & 475 & 1.04 & 26 \\
\hline Iceland & 473 & 0.93 & 5 \\
\hline Israel & 467 & 0.94 & 11 \\
\hline Malta & 465 & 0.98 & 14 \\
\hline Slovak Republic & 461 & 0.89 & 16 \\
\hline Greece & 455 & 0.91 & 13 \\
\hline Chile & 447 & 0.80 & 17 \\
\hline Bulgaria & 446 & 0.81 & 16 \\
\hline United Arab Emirates & 437 & 0.91 & 5 \\
\hline Uruguay & 435 & 0.72 & 16 \\
\hline Romania & 435 & 0.93 & 14 \\
\hline Cyprus $^{5}$ & 433 & 0.95 & 9 \\
\hline Moldova & 428 & 0.93 & 12 \\
\hline Albania & 427 & 0.84 & $\mathrm{~m}$ \\
\hline Turkey & 425 & 0.70 & 9 \\
\hline Trinidad and Tobago & 425 & 0.76 & 10 \\
\hline Thailand & 421 & 0.71 & 9 \\
\hline Costa Rica & 420 & 0.63 & 16 \\
\hline Qatar & 418 & 0.93 & 4 \\
\hline Colombia & 416 & 0.75 & 14 \\
\hline Mexico & 416 & 0.62 & 11 \\
\hline Montenegro & 411 & 0.90 & 5 \\
\hline Georgia & 411 & 0.79 & 11 \\
\hline Jordan & 409 & 0.86 & 9 \\
\hline Indonesia & 403 & 0.68 & 13 \\
\hline Brazil & 401 & 0.71 & 12 \\
\hline Peru & 397 & 0.74 & 22 \\
\hline Lebanon & 386 & 0.66 & 10 \\
\hline Tunisia & 386 & 0.93 & 9 \\
\hline FYROM & 384 & 0.95 & 7 \\
\hline Kosovo & 378 & 0.71 & 5 \\
\hline Algeria & 376 & 0.79 & 1 \\
\hline Dominican Republic & 332 & 0.68 & 13 \\
\hline
\end{tabular}


Countries/economies with higher performance or greater equity than the OECD average Countries with values not statistically different from the OECD average

Countries/economies with lower performance or less equity than the OECD average

\begin{tabular}{|c|c|c|c|c|c|c|}
\hline \multicolumn{3}{|c|}{ Inclusion and fairness indicators } & \multicolumn{4}{|c|}{ Difference between PISA 2006 and PISA 2015 (PISA 2015 - PISA 2006) } \\
\hline $\begin{array}{l}\text { Score-point difference } \\
\text { in science associated } \\
\text { with one-unit increase } \\
\text { on the ESCS }{ }^{1} \text { index }\end{array}$ & $\begin{array}{l}\text { Percentage of resilient } \\
\text { students }^{3}\end{array}$ & $\begin{array}{c}\text { Difference in science } \\
\text { performance between } \\
\text { immigrant and non-immigrant } \\
\text { students, after accounting for } \\
\text { ESCS and language spoken } \\
\text { at home } \\
\end{array}$ & $\begin{array}{c}\text { Percentage of variation } \\
\text { in science performance } \\
\text { explained by students' socio- } \\
\text { economic status }\end{array}$ & $\begin{array}{l}\text { Score-point difference } \\
\text { in science associated } \\
\text { with one-unit increase } \\
\text { on the ESCS index }\end{array}$ & $\begin{array}{l}\text { Percentage of resilient } \\
\text { students }\end{array}$ & $\begin{array}{l}\text { Difference in science } \\
\text { performance between } \\
\text { immigrant and non-immigrant } \\
\text { students, after accounting } \\
\text { for ESCS and language } \\
\text { spoken at home }\end{array}$ \\
\hline Score dif. ${ }^{2}$ & $\%$ & Score dif. & $\%$ dif. & Score dif. & $\%$ dif. & Score dif. \\
\hline 38 & 29.2 & 19 & -1.4 & 0 & 1.5 & -6 \\
\hline 47 & 48.8 & -13 & $\mathrm{~m}$ & $\mathrm{~m}$ & $\mathrm{~m}$ & $\mathrm{~m}$ \\
\hline 42 & 48.8 & 53 & 1.6 & 2 & 8.2 & $\mathrm{~m}$ \\
\hline 32 & 48.3 & 28 & -1.0 & 2 & 2.0 & -2 \\
\hline 45 & 46.3 & $\mathrm{~m}$ & 1.0 & 2 & 2.0 & $\mathrm{~m}$ \\
\hline 40 & 42.8 & 36 & 1.8 & 10 & -10.4 & -11 \\
\hline 12 & 64.6 & -19 & -0.1 & 0 & 5.8 & -2 \\
\hline 34 & 38.7 & -5 & 0.3 & 1 & 0.7 & -11 \\
\hline 23 & 75.5 & $\mathrm{~m}$ & $\mathrm{~m}$ & $\mathrm{~m}$ & $\mathrm{~m}$ & $\mathrm{~m}$ \\
\hline 19 & 61.8 & -1 & -1.5 & -8 & -0.7 & 10 \\
\hline 40 & 45.3 & 135 & $\mathrm{~m}$ & $\mathrm{~m}$ & $\mathrm{~m}$ & $\mathrm{~m}$ \\
\hline 44 & 40.4 & $\mathrm{~m}$ & 3.1 & 13 & $\begin{array}{l}3.2 \\
\end{array}$ & $\mathrm{~m}$ \\
\hline 49 & 30.4 & -3 & -2.0 & 0 & -4.7 & -9 \\
\hline 43 & 34.6 & 14 & -4.0 & -5 & 4.3 & 1 \\
\hline 44 & 32.9 & -13 & -0.4 & 2 & -0.2 & -8 \\
\hline 37 & 35.4 & 15 & -2.9 & -8 & 5.0 & 9 \\
\hline 42 & 33.5 & 28 & -4.0 & -5 & 8.7 & 7 \\
\hline 47 & 30.7 & 23 & $\begin{array}{l}3.8 \\
\end{array}$ & 3 & \begin{tabular}{|l|}
-1.3 \\
\end{tabular} & -10 \\
\hline 43 & 29.1 & 16 & -0.7 & 0 & 1.2 & -20 \\
\hline 38 & 29.6 & 3 & -0.5 & 1 & 0.4 & 6 \\
\hline 48 & 27.2 & 28 & -0.7 & 2 & 1.4 & -32 \\
\hline 34 & 27.5 & 38 & -3.6 & -7 & 7.9 & 7 \\
\hline 40 & 34.6 & $\mathrm{~m}$ & $\begin{array}{l}-1.4 \\
\end{array}$ & 0 & 3.2 & $\mathrm{~m}$ \\
\hline 31 & 38.1 & 8 & -1.4 & 3 & 4.4 & -49 \\
\hline 37 & 26.5 & 23 & -0.4 & 1 & 9.3 & 8 \\
\hline 33 & 31.6 & -5 & -6.0 & -13 & 12.3 & -10 \\
\hline 45 & 25.9 & 18 & 0.1 & 0 & -2.2 & $\begin{array}{l}-17 \\
\end{array}$ \\
\hline 57 & 26.6 & 20 & -1.9 & 5 & 3.0 & 10 \\
\hline 44 & 24.7 & 40 & 1.2 & 6 & 0.6 & 13 \\
\hline 52 & 24.9 & 2 & 2.7 & 1 & -3.9 & -20 \\
\hline 27 & 39.2 & 26 & 0.9 & 3 & 10.7 & -23 \\
\hline 26 & 35.2 & 14 & -0.5 & -4 & 6.0 & 7 \\
\hline 29 & 25.5 & 5 & -0.9 & 0 & -1.0 & -4 \\
\hline 41 & 20.7 & 22 & -1.7 & 2 & 1.5 & -16 \\
\hline 30 & 26.6 & 11 & -0.6 & -1 & 2.8 & -32 \\
\hline 47 & 19.3 & -11 & 0.3 & 2 & -6.7 & -13 \\
\hline 36 & 23.1 & 2 & -2.6 & -2 & -2.1 & 11 \\
\hline 38 & 24.4 & 14 & -0.1 & 3 & -0.5 & 7 \\
\hline 37 & 14.9 & 15 & $\mathrm{~m}$ & $\mathrm{~m}$ & $\mathrm{~m}$ & $\mathrm{~m}$ \\
\hline 28 & 17.0 & 53 & -2.6 & -3 & $\begin{array}{l}-1.8 \\
\end{array}$ & 24 \\
\hline 42 & 15.7 & -9 & 0.9 & 0 & 2.3 & 1 \\
\hline 47 & 21.8 & -5 & $m$ & $\mathrm{~m}$ & $\mathrm{~m}$ & $m$ \\
\hline 41 & 17.5 & 40 & -3.6 & -4 & -2.8 & $\mathrm{~m}$ \\
\hline 34 & 18.1 & 14 & -2.1 & -2 & -2.3 & 5 \\
\hline 32 & 14.6 & 21 & -6.4 & -6 & -0.4 & $\mathrm{~m}$ \\
\hline 41 & 13.6 & 49 & $\begin{array}{l}-6.3 \\
\end{array}$ & -7 & 4.1 & $\mathrm{~m}$ \\
\hline 30 & 7.7 & -77 & $\mathrm{~m}$ & $\mathrm{~m}$ & $\mathrm{~m}$ & $\mathrm{~m}$ \\
\hline 32 & 14.0 & 11 & -1.6 & -2 & -1.8 & $\mathrm{~m}$ \\
\hline 34 & 11.3 & $\mathrm{~m}$ & -1.5 & -1 & 4.8 & $\mathrm{~m}$ \\
\hline 31 & 10.1 & 1 & $\mathrm{~m}$ & $\mathrm{~m}$ & $\mathrm{~m}$ & $\mathrm{~m}$ \\
\hline 33 & 13.4 & 0 & $\mathrm{~m}$ & $\mathrm{~m}$ & $\mathrm{~m}$ & $\mathrm{~m}$ \\
\hline $\mathrm{m}$ & $\mathrm{m}$ & $\mathrm{m}$ & $\mathrm{m}$ & $\mathrm{m}$ & $\mathrm{m}$ & $\mathrm{m}$ \\
\hline 20 & 21.8 & 22 & -6.1 & -7 & $\begin{array}{l}-1.4 \\
\end{array}$ & 21 \\
\hline 31 & 12.9 & 19 & $\mathrm{~m}$ & $\mathrm{~m}$ & $\mathrm{~m}$ & $\mathrm{~m}$ \\
\hline 22 & 18.4 & -8 & -6.5 & -5 & -5.2 & $\mathrm{~m}$ \\
\hline 24 & 9.4 & 6 & $\mathrm{~m}$ & $\mathrm{~m}$ & $\mathrm{~m}$ & $\mathrm{~m}$ \\
\hline 27 & 5.7 & -77 & 2.4 & 15 & 4.9 & -19 \\
\hline 27 & 11.4 & 60 & 3.1 & 4 & 0.3 & $\mathrm{~m}$ \\
\hline 19 & 12.8 & 57 & -5.2 & -5 & $\begin{array}{l}-1.9 \\
\end{array}$ & -21 \\
\hline 23 & 9.4 & -7 & -2.6 & -1 & 1.8 & 12 \\
\hline 34 & 7.5 & 4 & $\mathrm{~m}$ & $\mathrm{~m}$ & $\mathrm{~m}$ & $\mathrm{~m}$ \\
\hline 25 & 7.7 & -2 & -1.6 & 0 & -6.6 & 13 \\
\hline 22 & 10.9 & $\mathrm{~m}$ & 3.5 & 1 & -4.1 & $\mathrm{~m}$ \\
\hline 27 & 9.4 & 64 & -4.5 & -1 & -0.9 & 30 \\
\hline 30 & 3.2 & 29 & $\mathrm{~m}$ & $\mathrm{~m}$ & $\mathrm{~m}$ & $\mathrm{~m}$ \\
\hline 26 & 6.1 & 18 & $\mathrm{~m}$ & $\mathrm{~m}$ & $\mathrm{~m}$ & $\mathrm{~m}$ \\
\hline 17 & 4.7 & 50 & 0.1 & -2 & -11.7 & -20 \\
\hline 25 & 4.1 & 23 & $\mathrm{~m}$ & $\mathrm{~m}$ & $\mathrm{~m}$ & $\mathrm{~m}$ \\
\hline 18 & 2.5 & 28 & $\mathrm{~m}$ & $\mathrm{~m}$ & $\mathrm{~m}$ & $\mathrm{~m}$ \\
\hline 8 & 7.4 & 33 & $\mathrm{~m}$ & $\mathrm{~m}$ & $\mathrm{~m}$ & $\mathrm{~m}$ \\
\hline 25 & 0.4 & 26 & $\mathrm{~m}$ & $\mathrm{~m}$ & $\mathrm{~m}$ & $\mathrm{~m}$ \\
\hline
\end{tabular}




\section{Policies and practices for successful schools}

What the data tell us

\section{Policies about learning science at school and performance in science}

- The approximately $6 \%$ of students across OECD countries who reported not attending any regular science lessons score 25 points lower than students who reported attending at least one science lesson, after accounting for the socio-economic profile of students and schools. In 34 school systems, particularly in Austria, Belgium, Croatia, France, Germany, the Slovak Republic and Chinese Taipei, the students who reported not attending regular science lessons are more likely to attend socio-economically disadvantaged schools than advantaged schools.

- Across OECD countries, socio-economically advantaged schools are considerably more likely than disadvantaged schools to offer science competitions and a science club as school activities.

- How much time students spend learning and how science is taught are even more strongly associated with science performance and the expectations of pursuing a sciencerelated career than how well-equipped and -staffed the science department is, which extracurricular science activities are offered at school and science teachers' qualifications.

- According to students' reports, and on average across OECD countries, teachers in advantaged schools explain or demonstrate a scientific idea (teacher-directed instruction) more frequently than do teachers in disadvantaged schools. Students who reported that their science teachers frequently use these practices and adapt their teaching to meet students' needs score higher in science, show stronger beliefs about the value of scientific enquiry, and are more likely to expect to pursue a science-related career than students who reported that their teachers use these practices less frequently.

\section{The learning environment}

- In most school systems, students in socio-economically disadvantaged schools are more likely to have skipped a day of school than students in advantaged schools. Between 2012 and 2015, the percentage of students who had skipped a whole day of school at least once in the two weeks prior to the PISA test increased by around 5 percentage points across OECD countries.
- Across OECD countries, school principals cited student truancy and staff resisting change as the problems that hinder student learning the most; they also reported that learning in their schools is least hindered by students' use of alcohol or illegal drugs, or students intimidating or bullying other students.

- Students in school systems that select students into different education programmes or types of schools at a later age reported receiving greater support from their teachers.

\section{School governance, assessment and accountability}

- Students in private schools score higher in science than students in public schools; but after accounting for the socioeconomic profile of students and schools, students in public schools score higher than students in private schools on average across OECD countries and in 22 education systems.

- Standardised tests are used extensively across PISAparticipating countries and economies. In about five out of six school systems, at least half of students are assessed at least once a year with mandatory standardised tests, and in about three out of four countries, at least half of students are assessed at least once a year with non-mandatory standardised tests.

- When choosing a school for their child, parents are more likely to consider important or very important that there is a safe school environment, that the school has a good reputation and that the school has an active and pleasant climate - even more so than the academic achievement of the students in the school.

\section{Selecting and grouping students}

- Thirty countries and economies used grade repetition less frequently in 2015 than in 2009; in only five countries did the incidence of grade repetition increase during the period. The use of grade repetition decreased by at least 10 percentage points in Costa Rica, France, Indonesia, Latvia, Macao (China), Malta, Mexico and Tunisia.

- Across OECD countries, socio-economically disadvantaged students, students with an immigrant background and boys are more likely to have repeated a grade, even after accounting for their academic performance, and their self-reported motivation and behaviour.

- The later students are first selected into different schools or education programmes and the less prevalent the incidence of grade repetition, the more equitable the school system, or the weaker the association between students' socio-economic status and their performance in science. 
Differences in the requirement to attend regular science lessons, by schools' socio-economic profile Results based on students' self-reports

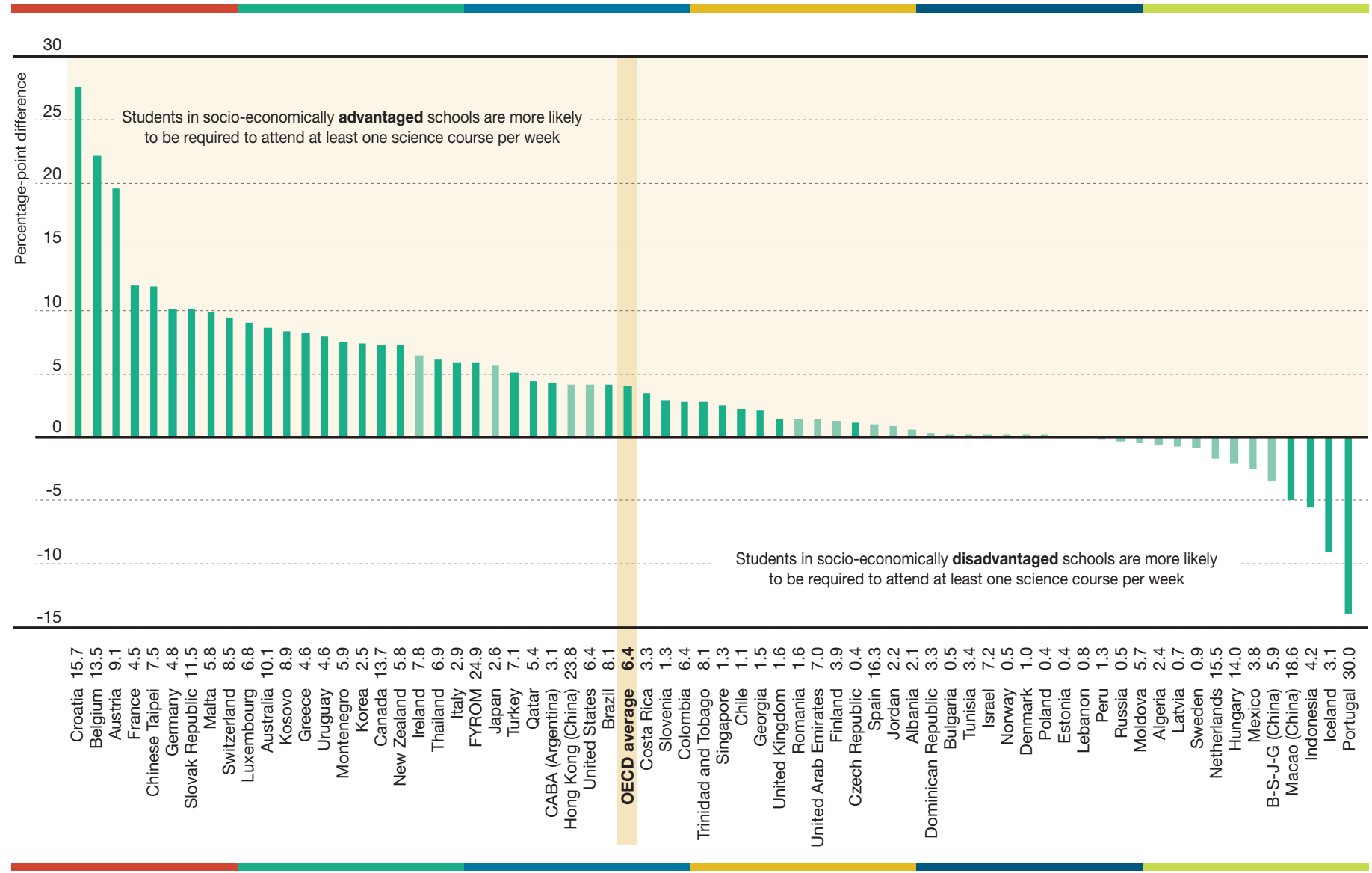

Notes: Statistically significant differences are marked in a darker tone.

The percentage of students who are not required to attend any science course is shown next to the country/economy name.

Countries and economies are ranked in descending order of the percentage-point difference between students in socio-economically advantaged and disadvantaged schools who are required to attend at least one science course per week.

Source: OECD, PISA 2015 Database, Table II.2.3.

\section{Resources invested in education}

- Students in larger schools score higher in science and are more likely than students in smaller schools to expect to work in a science-related occupation in the future. But students in smaller schools reported a better disciplinary climate in their science lessons and they are less likely than students in larger schools to skip days of school and arrive late for school, after accounting for schools' and students' socio-economic status.

- On average across OECD countries, students in smaller classes reported more frequently than students in larger classes that their teachers adapt their instruction to students' needs, knowledge and level of understanding.
- Students score five points higher in science for every additional hour spent per week in regular science lessons, after accounting for socio-economic status.

- School systems where students spend more time learning after school, by doing homework, receiving additional instruction or in private study, tend to perform less well in science. 
Even if all students do not have to learn the same science material, the opportunity to choose science courses need not become an opportunity not to learn science.

Students who do not attend any science lessons at school score 44 points lower in science than students who attend at least one science course per week, and in 21 countries and economies, the difference is at least 50 points. Their poor performance may be one of the reasons why these students do not take science courses in the first place; but cutting them off entirely from school science may only widen the gap with their better-performing peers.

All the correlational evidence in PISA suggests that learning science at school may be more effective than learning science after school. Students who spend more time learning science at school score higher in science, while this is not necessarily the case with students who spend more time learning science after school. Students also score higher in science than in mathematics and reading when they spend more time learning science at school than learning mathematics and the language of instruction at school. But this is less true when students spend more time learning science after school than learning mathematics and the language of instruction after school.

While changing how teachers teach is challenging, school leaders and governments should try to find ways to make teaching more effective.

What happens inside the classroom is crucial for students' learning and career expectations. How teachers teach science is more strongly associated with science performance and students' expectations of working in a science-related occupation than the material and human resources of science departments, including the qualifications of teachers or the kinds of extracurricular science activities offered to students. For instance, in almost all education systems, students score higher in science when they reported that their science teachers "explain scientific ideas", "discuss their questions" or "demonstrate an idea" more frequently. They also score higher in science, in almost all school systems, when they reported that their science teachers "adapt the lesson to their needs and knowledge" or "provide individual help when a student has difficulties understanding a topic or task".

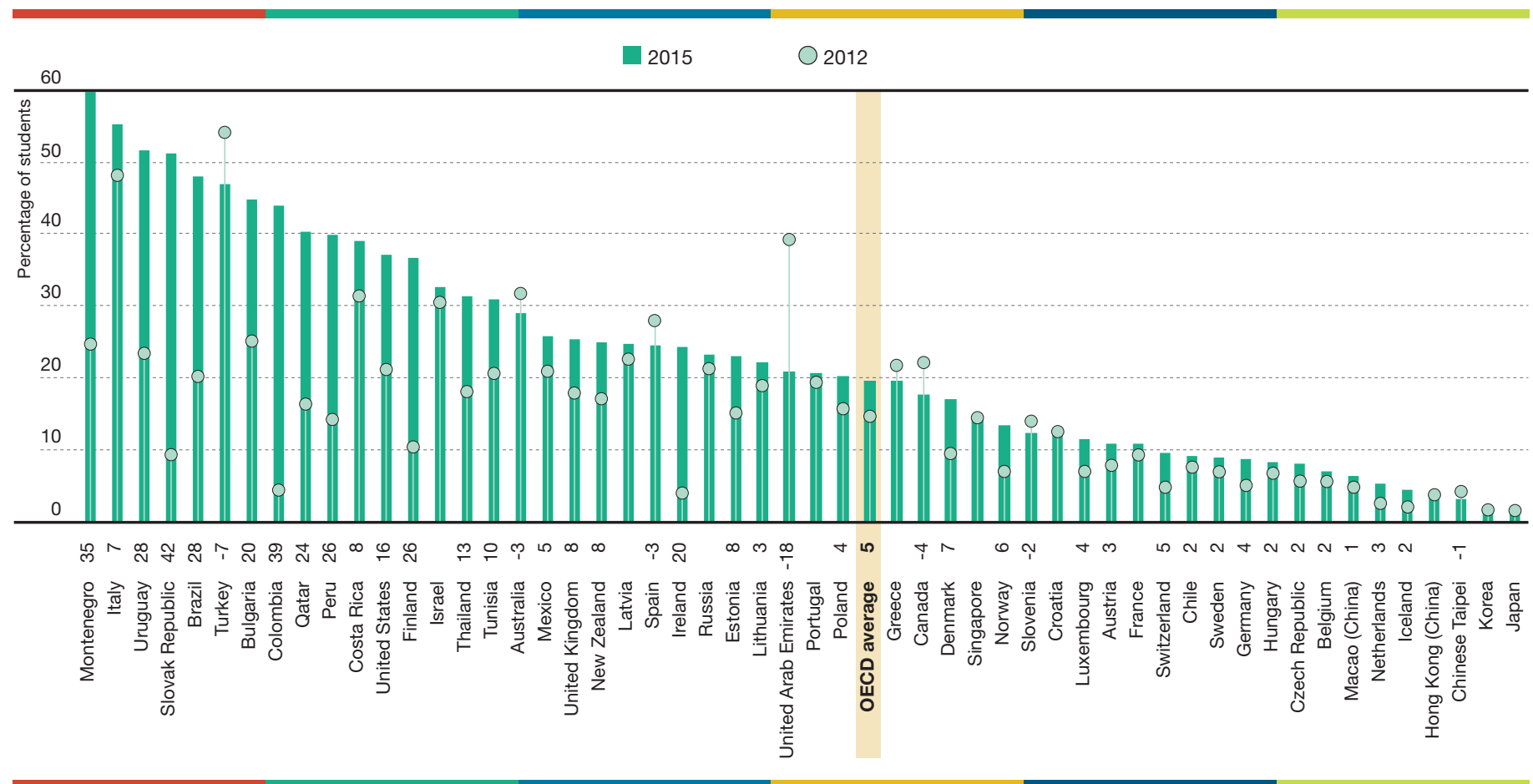

Notes: Only countries/economies that participated in both 2012 and 2015 PISA assessments are shown.

Only percentage-point differences between PISA 2012 and PISA 2015 that are statistically significant are shown next to the country/economy name.

Countries and economies are ranked in descending order of the percentage of students who had skipped a whole day of school at least once in the two weeks prior to the PISA test, in 2015.

Source: OECD, PISA 2015 Database, Tables II.3.1, II.3.2 and II.3.3. 
Correlations between the responsibilities for school governance ${ }^{1}$ and science performance

Results based on system-level analyses

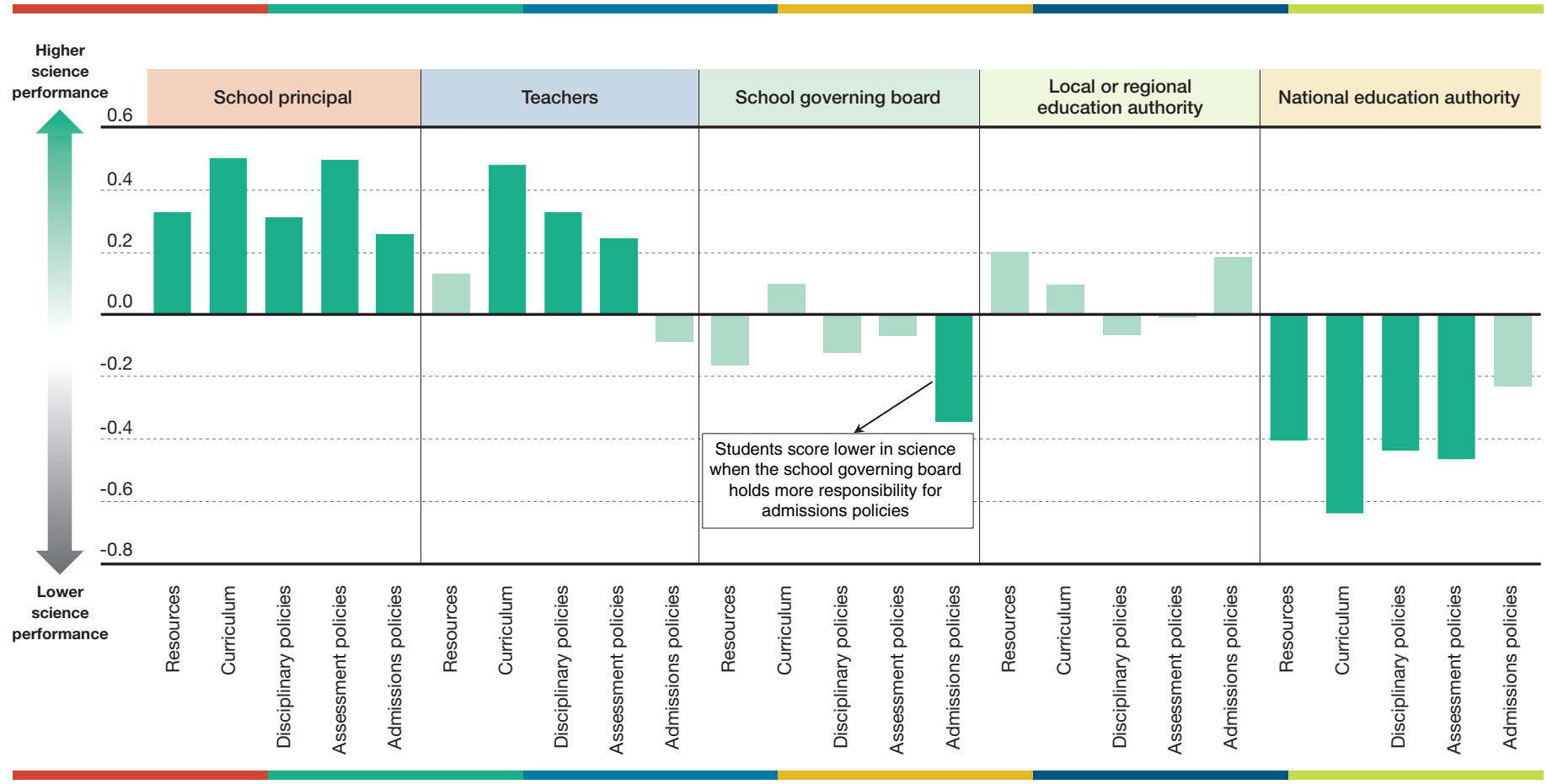

1. The responsibilities for school governance are measured by the share distribution of responsibilities for school governance in Table II.4.2 in PISA 2015 Results (Volume II): Policies and Practices for Successful Schools.

Notes: Results based on 70 education systems.

Statistically significant correlation coefficients are shown in a darker tone.

Source: OECD, PISA 2015 Database.

Granting schools more autonomy over the curriculum may give teachers more opportunities to adapt their instruction to students' needs and knowledge. Students score higher in science in education systems where principals exercise greater autonomy over resources, curriculum and other school policies - but especially so in countries where achievement data are tracked over time or posted publicly, or when principals show higher levels of educational leadership. These findings highlight the interplay between school autonomy and accountability already identified in earlier PISA assessments.

Experiments and hands-on activities can be inspiring and can help students develop a conceptual understanding of scientific ideas and transferable skills, such as critical thinking. But in order for these kinds of activities to be truly effective, school principals and teachers need to be prepared. Principals need to ensure that the laboratory material is in good shape and that teachers are supported and trained accordingly. Teachers need to design wellstructured laboratory activities that make tangible key scientific concepts and ideas, and help students make the links between the hands-on activities, scientific ideas and real-life problems. Students should also be made aware that when participating in these activities, they are manipulating ideas as well as objects.

\section{Provide additional support to disadvantaged schools.}

Learning should not be hindered by whether a child comes from a poor family, has an immigrant background, is raised by a single parent or has limited resources at home, such as no computer or no quiet room for studying. Successful education systems understand this and have found ways to allocate resources so as to level the playing field for students who lack the material and human resources that students in advantaged families enjoy. When more students learn, the whole system benefits. This is an important message revealed by PISA results: in countries and economies where more resources are allocated to disadvantaged schools, overall student performance in science is somewhat higher, particularly among OECD countries.

PISA data uncover a number of differences between disadvantaged and advantaged schools, both quantitative and qualitative, that collectively paint a picture of the drastically different learning environments in these distinct types of schools. Disadvantaged schools have fewer qualified science teachers and are less likely to require students to attend science classes. Their students not only spend less time in regular lessons than students in advantaged schools, they are also less exposed to quality 
teaching. For example, teachers in their schools are less likely to engage in some effective teaching strategies, such as explaining or demonstrating a scientific idea.

The range of learning opportunities beyond regular classes is also much narrower in disadvantaged schools, as these schools tend to offer fewer extracurricular activities, such as science competitions and clubs, sports, and music and arts activities. Disadvantaged schools also tend to be subject to more disciplinary problems and a lack of student engagement, manifested in students arriving late for school or skipping days of school, which compromise students' opportunities to learn and do well in school. Some of these differences between disadvantaged and advantaged schools are magnified in countries that practice early tracking.

Compensatory measures are essential and, in many ways, they are already in place in various countries. But further steps need to be taken. For example, it is not enough for disadvantaged schools to have more computers per student; these computers need to be connected to the Internet and, more important, they need to be used in a way that improves learning, not distracts from it. It is not enough for students in these schools to spend more time studying after school; they also need more time in regular lessons with better teaching, which is what their counterparts in advantaged schools already have. And they need more support after class, too, in the form of tutoring, and in enriching extracurricular activities, especially in countries and economies where students in advantaged schools spend more time studying after school, such as Croatia, Italy, Japan, Korea, Macao (China) and Chinese Taipei. Governments may need to provide additional resources for free-of-charge tutoring in disadvantaged schools so as to prevent the development of a shadow education system and to ensure equity in education opportunities.

Solutions will vary depending on the nature of the deficiency. But even when different schools face similar problems, tailored solutions that capitalise on assets already in place may be needed; and progress towards learning goals should be continuously monitored.

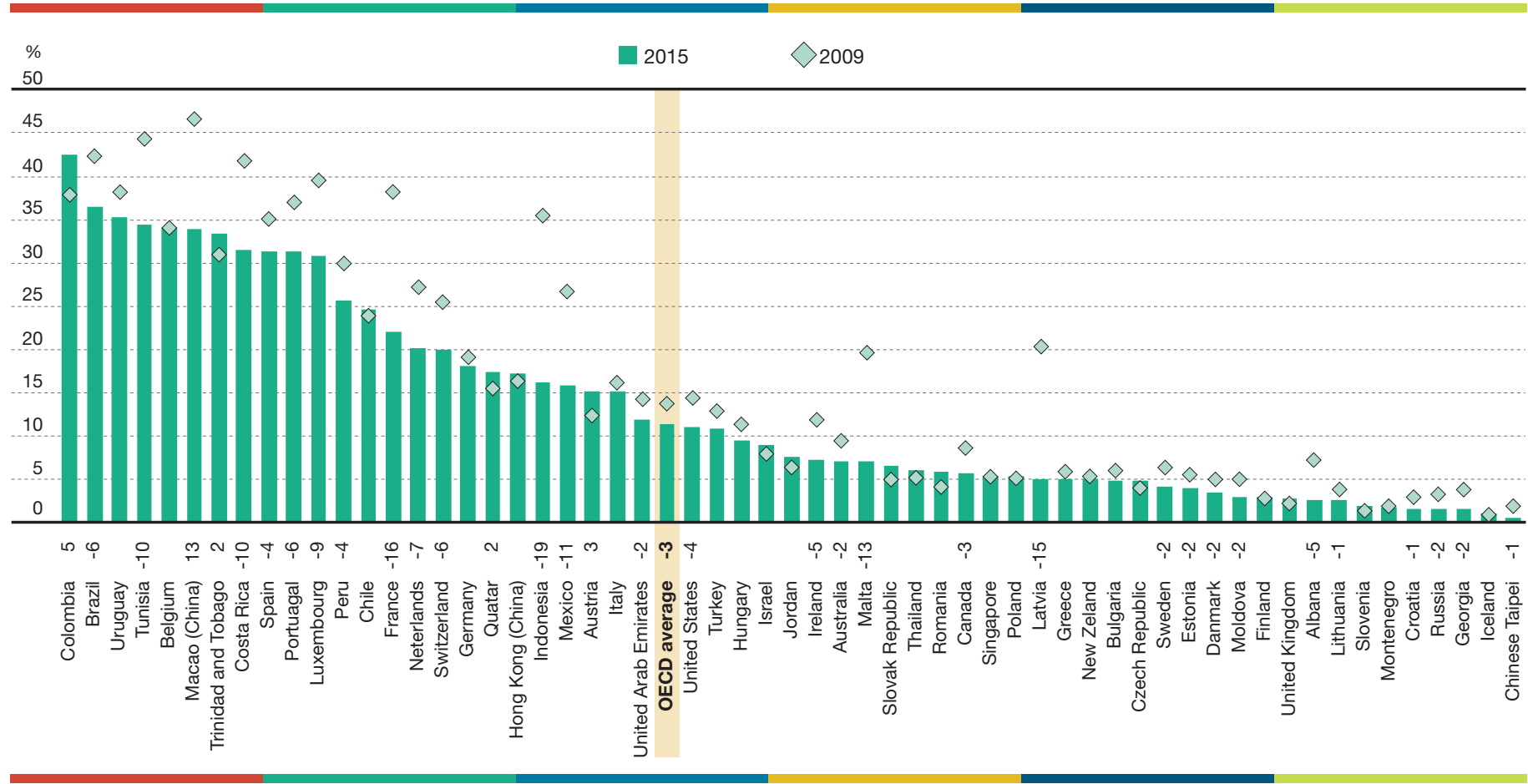

Notes: Statistically significant differences are shown next to the country/economy name.

Only countries and economies with comparable data from PISA 2009 and PISA 2015 are shown.

For Costa Rica, Georgia, Malta and Moldova, the change between PISA 2009 and PISA 2015 represents the change between 2010 and 2015 because these countries implemented the PISA 2009 assessment in 2010 as part of PISA 2009+.

Countries and economies are ranked in descending order of the percentage of students who had repeated a grade in 2015.

Source: OECD, PISA 2015 Database, Tables II.5.9, II.5.10 and II.5.11. 


\section{PISA 2015 Results}

Volume I, Excellence and Equity in Education, summarises student performance in PISA 2015, and examines inclusiveness and fairness in participating education systems.

Volume II, Policies and Practices for Successful Schools, examines how student performance is associated with various characteristics of individual schools and school systems.

Volume III (forthcoming), Students' Well-Being, describes how well adolescent students are learning and living.

Volume IV (forthcoming), Students' Financial Literacy, examines 15-year-old students' understanding about money matters in the 15 countries and economies that participated in this optional assessment.

Volume V (forthcoming), Collaborative Problem Solving, examines students' ability to work with two or more people to try to solve a problem.

This work is published under the responsibility of the Secretary-General of the OECD. The opinions expressed and arguments employed herein do not necessarily reflect the official views of OECD member countries.

This document and any map included herein are without prejudice to the status of or sovereignty over any territory, to the delimitation of international frontiers and boundaries and to the name of any territory, city or area.

The statistical data for Israel are supplied by and under the responsibility of the relevant Israeli authorities. The use of such data by the OECD is without prejudice to the status of the Golan Heights, East Jerusalem and Israeli settlements in the West Bank under the terms of international law.

B-S-J-G (China) refers to the four PISA-participating China provinces: Beijing, Shanghai, Jiangsu and Guangdong.

CABA (Argentina) refers to the adjudicated region of Ciudad Autónoma de Buenos Aires (CABA).

FYROM refers to the Former Yugoslav Republic of Macedonia.

Russia refers to the Russian Federation.

This work is available under the Creative Commons Attribution-NonCommercial-ShareAlike 3.0 IGO (CC BY-NC-SA 3.0 IGO). For specific information regarding the scope and terms of the licence as well as possible commercial use of this work or the use of PISA data please consult Terms and Conditions on www.oecd.org. 


\section{For more information, contact:}

Andreas Schleicher

Andreas.Schleicher@oecd.org

Visit:

www.oecd.org/pisa

\section{(2)) OECD}

